\title{
Preparing knowledge and Skill: Developing Speech Therapy Module in University
}

\author{
Khofidotur Rofiah, Endang Purbaningrum \\ Universitas Negeri Surabaya, Indonesia
}

\begin{abstract}
The speech therapy course is one of the subjects that must be taken by students who choose the deaf education specification in the Department of Extraordinary Education with the aim of being able to apply the concepts and skills of speech development to children with communication barriers in their environment later. Therefore, so that the lecture can take place effectively, it is necessary to prepare and plan based on the results of the study.

Development of learning tools in this study using the 4D-Model development design. This model was developed by S. Thagarajan, Dorothy S. Semmel, and Melvyn I. Semmel. The 4D development model consists of 4 main stages, namely: (1) Define, (2) Design (Design), (3) Develop (Development) and Disseminate (Distribution).

This research was carried out for 8 months, so that based on the development model design, research activities in the first year focused on implementing three stages, namely (1) defining, (2) planning / design, and (3) development. Research activities are primarily directed at developing prototypes of teaching speech books and their learning tools which consist of: (1) lecture plan equipped with rubric assessment and (5) textbooks.
\end{abstract}

Keywords: speech therapy course, development model design, and textbooks 